\title{
Percepção Ambiental e Uso do Solo por Agricultores de Sistemas Orgânicos e Convencionais na Chapada da Ibiapaba, Ceará
}

\author{
Guilherme Viana de Alencar ${ }^{1}$, Eduardo de Sá Mendonça ${ }^{2}$, \\ Téogenes Senna de Oliveira ${ }^{3}$, Ivo Jucksch ${ }^{4}$ e Paulo Roberto Cecon ${ }^{5}$
}

Resumo: $\mathrm{O}$ crescimento do mercado de alimentos livres de agrotóxicos vem gerando interesse de agricultores em sistemas orgânicos de produção. Os adeptos deste sistema promovem mudanças substanciais de seus métodos de produção, adquirindo conhecimentos técnicos e empíricos associados. São necessários, portanto, estudos para avaliar o sistema orgânico neste contexto, comparando-o com o modo de produção convencional, no que diz respeito aos aspectos socioeconômicos e ambientais. Este estudo teve como objetivo o diagnóstico regional desses aspectos em sistemas orgânicos e convencionais do distrito de Sussuanha, município de Guaraciaba do Norte, e do município de São Benedito, no estado do Ceará. Foram entrevistados sete agricultores orgânicos e 21 agricultores convencionais, caracterizando o meio social e as mudanças de qualidade de vida ocorridas com o tempo. As interações agricultor-meio ambiente, no sistema de produção orgânico, geraram melhoria da qualidade de vida das famílias. No sistema convencional, caracterizado pelo uso intensivo de agrotóxicos e grande dependência de adubos químicos, constatou-se que prevalece o interesse em obter a máxima produção sem preocupação com o ambiente. Esta condição se reflete no contato contínuo com agrotóxicos, além das margens de lucros restritivas, o que pode comprometer o uso do solo pelas futuras gerações, pois há uma inerente redução da fertilidade natural dos solos cultivados sob este sistema.

Palavras-chaves: Agricultura orgânica, agricultura convencional, degradação ambiental, sustentabilidade.

Abstract: The increase of the organic food market has been promoting the interest of farmers in the organic production systems. Agents who adopt this system implement

1 Analista Ambiental, IbamA/ES. E-mail: gvalencar@gmail.com

2 Professor do Departamento de Produção Vegetal, CCA, Universidade Federal do Espírito Santo. E-mail: eduardo.mendonca@ufes.br

3 Professor do Departamento de Solos, Universidade Federal de Viçosa. E-mail: teo@ufv.br

4 Professor do Departamento de Solos, Universidade Federal de Viçosa. E-mail: ivo@ufv.br

5 Professor do Departamento de Matemática, Universidade Federal de Viçosa. E-mail: cecon@dpi. ufv.br 
substantial changes in their production methods, by acquiring technical and empirical associated knowledge. Therefore, it is necessary to elaborate studies to evaluate organic agriculture systems in this scenario, comparing it with the conventional production model, focusing on social, economic and environmental aspects. This study aimed the regional diagnostic of the social, economic and environmental aspects of the organic and conventional agricultural systems in the Sussuanha district, located in North Guaraciaba and São Benedito municipalities (Ceará State). Seven farmers that practice organic agriculture were interviewed, as well as 20 conventional producers, characterizing all the social context and changes on life quality along the time. In the organic agricultural system, interactions between farmers and environment carried out the improvement of life quality. On the other hand, in the conventional production system, characterized by the use of pesticides and chemical fertilizers, the interest to obtain maximum production with no concerning with the environment prevails. This situation is a result of the continuous use of pesticides, marketing restrictions and land degradation by lowering the natural fertility of the soil on this type of production system.

Key-words: Organic agriculture, conventional agriculture, environmental degradation, sustainability.

Classificação JEL: Q15, Q19.

\section{Introdução}

Nos últimos anos, o número de adeptos da agricultura orgânica vem crescendo no Brasil, impulsionado pela demanda gerada por um mercado de consumidores que buscam alimentos produzidos sem agrotóxicos. De acordo com o Censo Agropecuário 2006 (IBGE, 2006), apenas $1,80 \%$ dos estabelecimentos agropecuários recenseados utilizam a agricultura orgânica. Neste segmento verifica-se a seguinte distribuição das atividades: pecuária e criação de outros animais (41,7\%); lavouras temporárias $(33,5 \%)$; lavoura permanente $(10,4 \%)$; horticultura/floricultura $(9,9 \%)$ e produção florestal $(3,8 \%)$.

As áreas de agricultura orgânica são pequenas quando comparadas ao total de áreas cultivadas no Brasil; porém, o crescimento anual estimado em $30 \%$ pode significar, no futuro, uma participação maior deste setor no mercado de alimentos (DAROLT, 2002).

Os consumidores urbanos, principalmente das grandes cidades, sentem diariamente os efeitos da redução da qualidade de vida causada por fatores antrópicos (poluição atmosférica, elevação da temperatura, sedentarismo, baixa longevidade etc) do modelo de desenvolvimento classificado como "moderno". O modelo social exige das famílias a adoção de praticidade e rapidez nas relações pessoais e profissionais, impulsionando o crescimento das indústrias de alimentos voltadas para a produção de alimentos prontos, congelados, enlatados e modificados, que ocupam as prateleiras dos supermercados e atendem os restaurantes de alimentação rápida (CERVEIRA e CASTRO, 1999; SOUZA e RESENDE, 2003).

Entretanto, a opção por esse tipo de alimento, dada a sua produção em larga escala, com o uso intenso de agrotóxicos e fertilizantes químicos, vem gerando problemas de saúde na população (SOUZA e RESENDE, 2003). Vislumbrando esse mercado promissor, muitos agricultores, na maioria classificados como familiares, começaram a produzir, individualmente ou em associação, produtos sem agrotóxicos. O sucesso deste produto é constatado pela fácil aceitação por parte dos consumidores e pela insuficiência de produção para atender a esse mercado.

Em uma visão mais ampla, a agricultura orgânica extrapola o simples objetivo de produzir sem agrotóxico, passando a agir positivamente no meio ambiente, nas relações trabalhistas, na cadeia produtiva e na saúde do homem do campo, buscando atingir um padrão sustentável de produção. 


\subsection{Objetivo}

Este trabalho propõe a avaliação dos impactos sociais, econômicos, culturais e ambientais ocasionados pela implantação do modelo de cultivo orgânico por agricultores dos municípios de Guaraciaba do Norte e São Benedito, no Ceará, em comparação com o modelo convencional predominante na região.

\section{Referencial teórico}

\subsection{Histórico da agricultura orgânica}

A agricultura convencional é descrita como o conjunto de técnicas produtivas que surgiram em meados do século XIX, conhecida como a $2^{\mathrm{a}}$ revolução agrícola, que teve como suporte o lançamento dos fertilizantes químicos por Liebig. Este sistema expandiu-se após as grandes guerras, com o emprego de sementes manipuladas geneticamente para o aumento da produtividade, associado ao emprego de agroquímicos (agrotóxicos e fertilizantes) e da maquinaria agrícola. O agricultor é dependente de tecnologias/recursos/capital do setor industrial, que, devido ao seu fluxo unidirecional, leva à degradação do ambiente e à descapitalização, criando uma situação insustentável em longo prazo (EHLERS, 1999).

A "Revolução Verde", ocorrida na agricultura após o término da Segunda Guerra Mundial, teve como principal característica o uso em larga escala de insumos químicos no intuito de elevar a produtividade agrícola. Embora essa mudança de paradigma na agricultura tenha nascido em países desenvolvidos, houve interesse em difundi-la mundialmente com a alegação de que iria acabar com a fome. Todo um pacote tecnológico (sementes melhoradas, fertilizantes químicos e agrotóxicos) foi vendido para os países em desenvolvimento e subdesenvolvidos. Decorridos 50 anos, observam-se problemas como: pragas resistentes a agrotóxicos; contaminação da água, do solo e dos alimentos; eliminação de inimigos naturais; erosão, compactação e salinização do solo; e êxodo rural, devido à mecanização da produção (ROSSET, 1995; WATANABE, 2000).

O modelo agrícola implantado com a "Revolução Verde", embora tivesse contribuído para os sucessivos recordes de produtividade agrícola e redução da pressão do desmatamento em áreas nativas, não se traduziu num modelo sustentável (PRIMAVESI, 2001). A sustentabilidade de um sistema agrícola requer o uso racional dos recursos naturais, tendo em vista a perpetuidade produtiva deste bem. O modelo convencional de agricultura requer um aporte elevado e contínuo de insumos industriais (fertilizantes, defensivos químicos etc.) para a manutenção do sistema, apresentando baixa eficiência no uso de energia (GLIESSMAN, 2000).

Contrapondo-se a esse modelo, surgiu uma corrente de pensamento intitulado "agricultura alternativa", em que a filosofia da produção baseia-se na sustentabilidade do sistema. Agricultura biodinâmica, ecológica e orgânica, entre várias correntes, propõem um paradigma agrícola dentro dos princípios ecológicos. O uso eficiente da energia no sistema e a reduzida dependência de recursos externos para produção atraem vários adeptos interessados no cultivo ecológico, cujos produtos visam atender ao mercado de consumidores orgânicos (ASSIS et al., 1995; CERVEIRA e CASTRO, 1999; GLIESSMAN, 2000).

Os agroecossistemas alternativos buscam atingir a sustentabilidade por meio da conservação dos recursos renováveis, adaptando a agricultura ao ambiente, com a manutenção de um nível alto e sustentável de produtividade (ALTIERI, 1989). Nesse contexto, a sustentabilidade só é alcançada por meio da adoção de práticas agrícolas fundamentadas pelo conhecimento dos processos ecológicos que acontecem nas áreas produtivas e, em dimensão mais ampla, no meio ambiente em que ela se insere (ROBERTS, 1995; GLIESSMAN, 2000).

O conceito de sustentabilidade é amplo, havendo diversas definições de agricultura sustentável, e todas incorporam os seguintes itens (EHLERS, 1999): 
- Manutenção em longo prazo dos recursos naturais e da produtividade agrícola;

- O mínimo de impactos adversos ao ambiente;

- Retornos adequados aos produtores;

- Otimização da produção das culturas com o mínimo de insumos químicos;

- Satisfação das necessidades humanas de alimentos e de renda;

- Atendimento das necessidades sociais das famílias e das comunidades rurais.

Em sistemas de cultivos orgânicos, a manutenção da produtividade elevada depende do conhecimento da dinâmica da matéria orgânica do solo (MIYASAKA et al., 1997). Esse conhecimento abrange aspectos relacionados ao destino da matéria orgânica aplicada ao solo, mecanismos de transformação e reação de seus componentes e subprodutos, assim como seus efeitos no solo (MIYASAKA et al., 1997).

A agricultura orgânica é o sistema de produção que exclui o uso de fertilizantes sintéticos de alta solubilidade, agrotóxicos, reguladores de crescimento e aditivos para a alimentação animal, compostos sinteticamente (AAO, 2005). É baseado em técnicas que conduzem ao uso equilibrado do solo. Práticas como o preparo mecânico do solo com baixo impacto na estrutura, aplicação de adubos orgânicos, uso de adubação verde com leguminosas, adoção de cobertura morta, manejo de plantas espontâneas, uso de biofertilizantes e adubações minerais auxiliares de baixa solubilidade (SOUZA, 2000).

\subsection{Agricultura orgânica no Brasil}

O modelo agrícola de produção orgânica foi implantado no Brasil no início da década de 70, ocasião em que ocorria discussão sobre os impactos causados pela agricultura convencional no País. Até 1995, o desenvolvimento da agricultura orgânica no Brasil aconteceu em ritmo lento, mesmo com a criação de fundações e institutos direcionados ao estudo do sistema orgânico (Instituto Biodinâmico, Instituto Verde
Vida de Desenvolvimento Rural e Associação de Agricultura Orgânica, dentre outros). Após este período é que se observa o aumento de adeptos ao cultivo orgânico, impulsionados pela demanda por seus produtos gerada por consumidores conscientes da importância nutricional da alimentação orgânica (DAROLT, 2002).

Em 2008, o Ministério da Agricultura, Pecuária e Abastecimento aprovou o Regulamento Técnico para os Sistemas Orgânicos de Produção Animal e Vegetal através da Instrução Normativa n. 64 (MAPA, 2008). Segundo esta instrução, os requisitos gerais dos sistemas orgânicos de produção devem contemplar aspectos ambientais, econômicos e sociais, conforme caracterização abaixo:

Aspectos ambientais (Art. 3):

- a manutenção das áreas de preservação permanente;

- a atenuação da pressão antrópica sobre os ecossistemas naturais e modificados;

- a proteção, a conservação e o uso racional dos recursos naturais.

Aspectos econômicos (Art. 4):

- o melhoramento genético, visando a adaptabilidade às condiçóes ambientais locais;

- a manutenção e a recuperação de variedades locais, tradicionais ou crioulas, ameaçadas pela erosão genética;

- a promoção e a manutenção do equilíbrio do sistema de produção como estratégia de promover a sanidade dos animais e vegetais;

- a interação da produção animal e vegetal;

- a valorização dos aspectos culturais e a regionalização da produção.

Aspectos Sociais (Art. 5):

- relações de trabalho fundamentadas nos direitos sociais determinados pela Constituição Federal;

- a melhoria da qualidade de vida dos agentes envolvidos em toda a rede de produção orgânica.

O Brasil apresenta um mercado consumidor de produtos orgânicos em franca ascensão, que, 
junto à demanda internacional por gêneros agrícolas ecologicamente produzidos, estimulam a adesão de agricultores de várias regiões brasileiras a converter o sistema convencional para orgânico (ASSIS et al., 1995; CERVEIRA e CASTRO, 1999). Em 2004, uma previsão apontou que o Brasil exportaria, naquele ano, 115 milhões de dólares em alimentos de produção orgânica devidamente certificados, com destaque para soja e o café (APEX, 2005).

\subsection{A agricultura orgânica no \\ Ceará e na Chapada da Ibiapaba}

O estado do Ceará apresenta aproximadamente $90 \%$ de sua área situada no semiárido, e o restante, em ambientes úmidos. As agriculturas de subsistência e tradicional caracterizam a maioria das pequenas propriedades, enquanto que extensas áreas são destinadas aos grandes projetos de irrigação voltados para fruticultura, alicerçados no uso maciço de insumos (ICID, 1992). Algumas iniciativas de sistemas agrícolas alternativos vêm sendo implantadas em várias áreas do estado, com maior ênfase para sistemas de cultivo orgânico.

Uma das primeiras experiências para implantar a proposta da agricultura orgânica no Nordeste do Brasil aconteceu no município de Tauá (CE), no período de 1991-1996. O Centro de Pesquisa e Assessoria (Esplar) organizou agricultores desse município para realizarem o manejo ecológico do algodoeiro arbóreo, visando a convivência produtiva com o bicudo (LIMA, 2001). A base deste projeto era fundamentada em dois pontos básicos: 1. a conservação do solo e a recuperação da sua fertilidade; 2 . a melhoria da qualidade da semente utilizada nos plantios (LIMA e JOCA, 1990).

A agricultura desenvolvida na região da Chapada da Ibiapaba é caracterizada predominantemente pela produção de olerícolas, seguindo-se o modelo convencional de produção, em que o uso de agrotóxicos e adubos químicos em quantidades abusivas configuram a estrutura desse modelo. A dependência de apor- tes energéticos e financeiros elevados caracteriza o sistema de produção convencional que gera uma produção final de alto impacto ecológico, elevado custo energético e baixa margem de lucro aos agricultores. Somando-se a este panorama e agravando-o, tem-se a redução da qualidade de vida dos produtores e consumidores de produtos convencionais, consequência dos efeitos nocivos dos agrotóxicos utilizados no manejo das culturas.

Os impactos ambientais causados pela agricultura convencional em Guaraciaba do Norte vêm tendo destaque nos meios de comunicação em massa, principalmente devido à contaminação humana e ambiental proveniente do uso abusivo de agrotóxicos. A importância deste fato passa a ter interesse maior da opinião pública em virtude de a região ser considerada um celeiro de produtos hortifrutigranjeiros para o estado do Ceará.

A agricultura orgânica vem apresentando desenvolvimento substancial na região da Chapada da Ibiapaba, estado do Ceará, principalmente no município de Guaraciaba do Norte, onde alguns agricultores com passado de cultivo convencional aderiram ao sistema orgânico de produção, visando abastecer com produtos orgânicos a Associação para o Desenvolvimento da Agropecuária Orgânica (Adao), sediada em Fortaleza (CE) e constituída por 460 associados. Esses agricultores aderiram ao sistema orgânico de produção visando obter melhoria da qualidade de vida, comprometida até então pelo uso indiscriminado de agrotóxicos e contaminação dos produtos agrícolas (MAPURUNGA, 2000).

\section{Metodologia}

\subsection{Caracterização das áreas de estudo}

O presente trabalho foi desenvolvido em propriedades agrícolas que adotam os sistemas de cultivo orgânico e convencional nos municípios de Guaraciaba do Norte e São Benedito, estado do Ceará, no período de abril a junho de 2003. 
O município de Guaraciaba do Norte está localizado na Chapada da Ibiapaba, região noroeste do estado, distando $320 \mathrm{~km}$ da capital Fortaleza, apresentando: latitude de $04^{\circ} 10^{\prime} 01^{\prime \prime} \mathrm{S}$ e longitude de $40^{\circ} 44^{\prime} 51^{\prime \prime} \mathrm{W}$, área de $611,461 \mathrm{~km}^{2}$ e altitude de $902 \mathrm{~m}$. A vegetação predominante na região é do tipo Carrasco (vegetação xerófila arbustiva densa alta) nas áreas mais secas e de baixa pluviosidade, e floresta subperenifólia tropical plúvio-nebular nas regiões serranas e de mata úmida. A unidade geomorfológica em que se encontra o município é denominada de Superfície Cuestiforme do Planalto da Ibiapaba, com classes de solo predominantes referidas como Neossolos Quartzarênicos e Latossolos. A economia do município é predominantemente agrícola, com mais da metade da população de 37.775 habitantes residente na zona rural (IBGE, 2010; IPECE, 2011; APRECE, 2012).

Dados da Fundação Cearense de Meteorologia e Recursos Hídricos (FUNCEME, 2003) mostram pluviosidade média anual do município de 1.243 $\mathrm{mm}$, irregularmente distribuída ao longo do ano e com concentração nos meses de janeiro a junho. A temperatura média das máximas é de $32^{\circ} \mathrm{C}$ e a das mínimas, de $20^{\circ} \mathrm{C}$.

A maior parte da população de Guaraciaba do Norte reside no meio rural $(53,93 \%)$, e esse setor tem participação na economia do município de 35,28\% (IPECE, 2011). O perfil agrário é caracterizado pela existência de 998 propriedades rurais, sendo que $95,79 \%$ do total é representado por pequenas propriedades com área de até 50 ha. Por se constituir em região potencialmente produtora de olerícolas, destinadas ao abastecimento da capital Fortaleza e de outros municípios circunvizinhos, esta atividade é considerada como de alta prioridade para efeito de financiamento agrícola pelo Banco do Nordeste (IPLANCE, 1998).

Os solos existentes nas áreas da pesquisa, baseado em critérios do Sistema Brasileiro de Classificação de Solos (EMBRAPA, 1999), são classificados como NEOSSOLO QUARTZARÊNICO Órtico típico. Os conteúdos de areia estão acima de $80 \%$, e de argila, abaixo de $15 \%$ na superfície e subsuperfície do solo (Tabela 1), o que enquadra este solo na classificação textural de arenoso. As principais características químicas de um solo de referência (mata) das áreas de estudo podem ser observadas na Tabela 2.

A escolha deste município é devida ao destaque no uso exagerado e indiscriminado de agrotóxicos no cultivo de olerícolas no estado do Ceará, gerando casos de intoxicação de agricultores, assim como pelo fato de alguns agricultores terem desenvolvido uma agricultura isenta de agroquímicos (agricultura orgânica), representando uma nova proposta de produção que se preocupa com a qualidade de vida do homem

Tabela 1. Características físicas das camadas de solo da área de referência (mata) no município de Guaraciaba do Norte (CE)

\begin{tabular}{lccccccc}
\hline \multicolumn{1}{c}{ Característica } & \multicolumn{7}{c}{ Profundidade $(\mathrm{cm})$} \\
\cline { 2 - 7 } & $0-10$ & $10-20$ & $20-30$ & $30-40$ & $40-60$ & $60-80$ & $80-100$ \\
\hline Areia Total $\left(\mathrm{g} \mathrm{kg}^{-1}\right)$ & 874 & 888 & 879 & 877 & 848 & 843 & 826 \\
Areia m. grossa $\left(\mathrm{g} \mathrm{kg}^{-1}\right)$ & 15 & 17 & 9 & 16 & 23 & 25 & 18 \\
Areia grossa $\left(\mathrm{g} \mathrm{kg}^{-1}\right)$ & 175 & 153 & 148 & 88 & 138 & 143 & 151 \\
Areia média $\left(\mathrm{g} \mathrm{kg}^{-1}\right)$ & 398 & 417 & 413 & 358 & 423 & 363 & 403 \\
Areia fina $\left(\mathrm{g} \mathrm{kg}^{-1}\right)$ & 257 & 270 & 282 & 371 & 226 & 270 & 208 \\
Areia m. fina $\left(\mathrm{g} \mathrm{kg}^{-1}\right)$ & 29 & 31 & 27 & 44 & 38 & 42 & 46 \\
Silte $\left(\mathrm{g} \mathrm{kg}^{-1}\right)$ & 28,50 & 35,8 & 17,5 & 31 & 32 & 38,5 & 52,5 \\
Argila $\left(\mathrm{g} \mathrm{kg}^{-1}\right)$ & 98,50 & 78 & 106,5 & 100 & 124 & 127 & 128,5 \\
Argila disp. em água $\left(\mathrm{g} \mathrm{kg}^{-1}\right)$ & 50 & 36 & 48 & 54 & 67,5 & 70 & 101 \\
Grau de floculação $(\%)$ & 49 & 54 & 55 & 46 & 46 & 45 & 21 \\
Textura & Arenosa & Arenosa & Arenosa & Arenosa & Arenosa & Arenosa & Arenosa \\
\hline
\end{tabular}

Fonte: Alencar (2005). 
Tabela 2. Características químicas das camadas de solo da área de referência (mata) no município de Guaraciaba do Norte (CE)

\begin{tabular}{|c|c|c|c|c|c|c|c|}
\hline \multirow{2}{*}{ Característica } & \multicolumn{7}{|c|}{ Profundidade $(\mathrm{cm})$} \\
\hline & $0-10$ & $10-20$ & $20-30$ & $30-40$ & $40-60$ & $60-80$ & $80-100$ \\
\hline pH em água & 4,66 & 4,62 & 4,54 & 4,54 & 4,79 & 4,94 & 4,80 \\
\hline $\mathrm{CE}, \mathrm{dS} \mathrm{m}$ & 0,72 & 0,59 & 0,21 & 0,10 & 0,26 & 0,13 & 0,20 \\
\hline $\mathrm{P}, \mathrm{mg} \mathrm{dm^{3 }}$ & 1,8 & 1,0 & 0,8 & 0,5 & 0,2 & 0,2 & 0,2 \\
\hline $\mathrm{K}^{+}, \mathrm{mg} \mathrm{dm}^{-3}$ & 23 & 12 & 10 & 8 & 4 & 6 & 6 \\
\hline $\mathrm{Na}^{+}, \mathrm{cmol}_{\mathrm{c}} \mathrm{dm}^{-3}$ & 1,0 & 0,0 & 0,0 & 0,0 & 0,0 & 0,0 & 10,0 \\
\hline $\mathrm{Ca}^{2+}, \mathrm{cmol}_{\mathrm{c}} \mathrm{dm}^{-3}$ & 0,45 & 0,00 & 0,00 & 0,00 & 0,00 & 0,08 & 0,00 \\
\hline $\mathrm{Mg}^{2+}, \mathrm{cmol}_{\mathrm{c}} \mathrm{dm}^{-3}$ & 0,33 & 0,11 & 0,09 & 0,08 & 0,06 & 0,08 & 0,08 \\
\hline $\mathrm{Al}^{3+}, \mathrm{cmol}_{\mathrm{c}} \mathrm{dm}^{-3}$ & 0,60 & 0,80 & 1,00 & 1,00 & 0,80 & 0,80 & 0,80 \\
\hline $\mathrm{H}^{+}+\mathrm{Al}^{+}, \mathrm{cmol}_{\mathrm{c}} \mathrm{dm}^{-3}$ & 5,6 & 4,9 & 4,9 & 5,3 & 4,3 & 4,3 & 4,3 \\
\hline $\mathrm{SB}, \mathrm{cmol}_{\mathrm{c}} \mathrm{dm}^{-3}$ & 0,84 & 0,14 & 0,12 & 0,10 & 0,07 & 0,18 & 0,14 \\
\hline $\mathrm{CTC}_{\mathrm{e}}, \mathrm{cmol}_{\mathrm{c}} \mathrm{dm}^{-3}$ & 1,44 & 0,94 & 1,12 & 1,10 & 0,87 & 0,98 & 0,94 \\
\hline $\mathrm{CTC}_{\mathrm{T}}, \mathrm{cmol}_{\mathrm{c}} \mathrm{dm}^{-3}$ & 6,44 & 5,04 & 5,02 & 5,4 & 4,37 & 4,48 & 4,44 \\
\hline $\mathrm{V}, \%$ & 13 & 2,8 & 2,4 & 1,9 & 1,6 & 4 & 3,2 \\
\hline $\mathrm{m}, \%$ & 41,7 & 85,1 & 89,3 & 90,9 & 92 & 81,6 & 85,1 \\
\hline P rem, $\mathrm{mg} \mathrm{cm}^{-3}$ & 40 & 36,2 & 32,2 & 30,1 & 26,5 & 22,8 & 22,6 \\
\hline
\end{tabular}

Fonte: Alencar (2005).

do campo, a qualidade dos produtos produzidos, o meio ambiente, e atende a demanda de consumidores que buscam alimentos produzidos sem agrotóxicos (MAPURUNGA, 2000; EMBRAPA, 2011; COGERH, 2012).

As análises laboratoriais (compostos; manancial de água; adubação verde) foram realizadas em amostras obtidas em 4 (quatro) propriedades orgânicas de referência localizadas no distrito de Sussuanha, município de Guaraciaba do Norte (CE) (Figura 1).

As demais propriedades (três orgânicas e 21 convencionais) foram escolhidas aleatoriamente na região para obtenção do diagnóstico regional. Quanto ao município de São Benedito (CE), os agricultores de sistemas orgânicos e convencionais foram selecionados com o objetivo de complementar a amostragem da pesquisa realizada por meio de entrevistas (diagnóstico regional).

Após a seleção das áreas de estudo, procedeu-se a caracterização do seu meio físico por meio do levantamento do histórico de cultivo, manejo etc. O levantamento destas informações foi proveniente do depoimento dos proprietários, assim como da observação "in loco" dos procedimentos técnicos realizados no manejo do solo.

O sistema orgânico de cultivo é caracterizado pela adubação orgânica (biofertilizantes, compostagem e adubação verde com várias espécies), controle de pragas e doenças com uso de inseticidas naturais, incorporação de restos culturais, rotação e consorciação de culturas. As práticas objetivam a melhoria da qualidade biológica do solo (Tabela 3). 
Figura 1. Localização das quatro áreas de referência de sistema de cultivo orgânico no distrito de Sussuanha, município de Guaraciaba do Norte, estado do Ceará
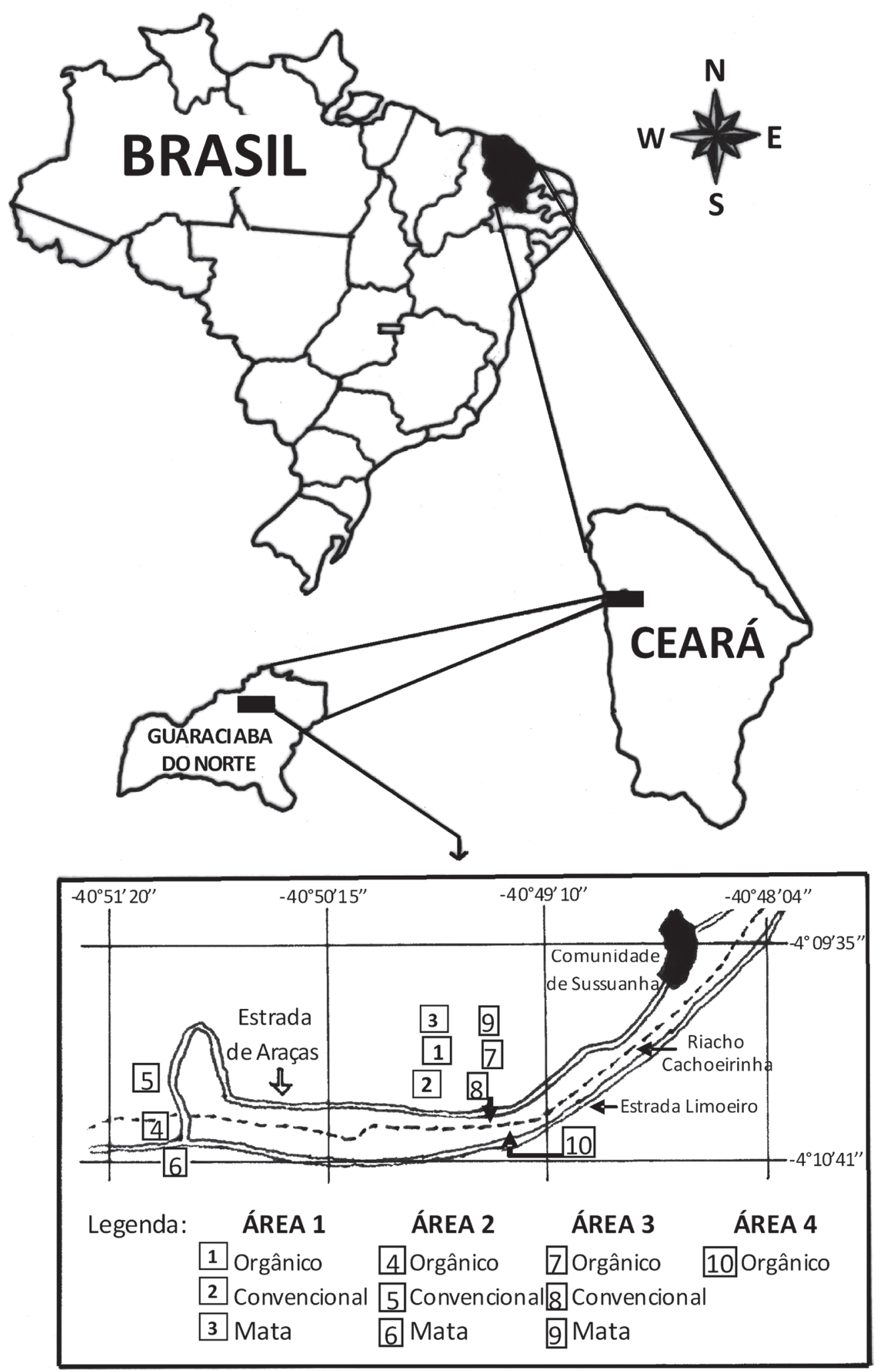

Fonte: Alencar (2005). 
Tabela 3. Sequência de práticas de manejo do solo e da cultura adotadas em sistema de produção orgânica na Chapada da Ibiapaba (CE)

\begin{tabular}{|c|c|c|c|}
\hline Etapa & Atividade & Objetivo & Caracterização \\
\hline 1 & $\begin{array}{l}\text { Aração ou } \\
\text { gradagem }\end{array}$ & $\begin{array}{l}\text { Incorporar ao solo a } \\
\text { vegetação nativa (pioneira) } \\
\text { com a gradagem, ou então } \\
\text { da adubação verde (área já } \\
\text { cultivada) por meio da aração }\end{array}$ & Prática realizada com uso do trator. \\
\hline 2 & Calagem & $\begin{array}{l}\text { Melhorar o pH do solo para } \\
\text { nível satisfatório }\end{array}$ & $\begin{array}{l}\text { A calagem é feita com calcário dolomítico uma única vez em áreas } \\
\text { pioneiras no cultivo orgânico, aplicando-se } 2 \text { ton./ha. Após passar } \\
\text { a grade na vegetação nativa (etapa } 1) \text {, aplica-se o calcário e faz-se } \\
\text { nova gradagem. Se a área foi cultivada antes, usa-se apenas o } \\
\text { fosfato de rocha ( } 0,8 \text { ton./ha). }\end{array}$ \\
\hline 3 & $\begin{array}{l}\text { Levantamento } \\
\text { dos canteiros }\end{array}$ & $\begin{array}{l}\text { Criar espaços para plantio e } \\
\text { desenvolvimento das plantas } \\
\text { olerícolas }\end{array}$ & $\begin{array}{l}\text { Nesta etapa, os canteiros são construídos com as dimensões de } \\
2 \text { m de largura por } 18 \text { a } 20 \text { m de comprimento. O trabalho é feito } \\
\text { utilizando implementos manuais, } 20 \text { dias após a incorporação da } \\
\text { adubação verde ou imediatamente após a aplicação do calcário. }\end{array}$ \\
\hline 4 & $\begin{array}{l}\text { Adubação } \\
\text { orgânica de } \\
\text { fundação }\end{array}$ & $\begin{array}{l}\text { Elevar os teores de matéria } \\
\text { orgânica do solo e melhorar a } \\
\text { nutrição das plantas }\end{array}$ & $\begin{array}{l}\text { É realizada após o levantamento dos canteiros, utilizando-se } \\
\text { composto orgânico na quantidade de } 12 \mathrm{~kg} / \mathrm{m}^{2} \text { (áreas pioneiras) } \\
\text { ou } 4 \mathrm{~kg} / \mathrm{m}^{2} \text { (área já cultivada). O esterco que compõe o composto } \\
\text { provém do sertão, onde as criações de gado geralmente são } \\
\text { manejadas semi-intensiva e sem aditivos químicos. }\end{array}$ \\
\hline 5 & Plantio & $\begin{array}{l}\text { Cultivar as plantas olerícolas } \\
\text { de interesse dos consumidores } \\
\text { orgânicos }\end{array}$ & $\begin{array}{l}\text { O plantio é feito de forma manual, sendo utilizadas sequências de } \\
\text { dois a três canteiros paralelos por olerícolas de famílias botânicas } \\
\text { distintas (Aliáceas, Brassicáceas, Asteráceas, Cucurbitáceas, } \\
\text { Quenopodiáceas, entre outras). A consorciação é feita com } \\
\text { culturas de grande porte (feijão, milho, mandioca etc) em outras } \\
\text { áreas. }\end{array}$ \\
\hline 6 & $\begin{array}{l}\text { Adubação de } \\
\text { manutenção }\end{array}$ & $\begin{array}{l}\text { Realizada com a finalidade de } \\
\text { complementar a adubação de } \\
\text { fundação }\end{array}$ & $\begin{array}{l}\text { É feita com composto (a quantidade é determinada } \\
\text { empiricamente, dependendo do comportamento do solo após a } \\
\text { primeira colheita no canteiro). Geralmente aplica-se } 1 \mathrm{~kg} \text { por m² e } \\
\text { biofertilizante (pulverização foliar). }\end{array}$ \\
\hline 7 & $\begin{array}{l}\text { Controle de } \\
\text { pragas e } \\
\text { doenças }\end{array}$ & $\begin{array}{l}\text { Redução do nível de ataque para } \\
\text { uma situação economicamente } \\
\text { viável }\end{array}$ & $\begin{array}{l}\text { Utiliza-se preparados de nim, caldas bordalesa e sulfocálcica, } \\
\text { manipueira, biofertilizantes, entre outros. }\end{array}$ \\
\hline 8 & Colheita & $\begin{array}{l}\text { Obtenção da produção } \\
\text { para atender o mercado de } \\
\text { consumidores orgânicos }\end{array}$ & Realizada duas vezes por semana de forma manual. \\
\hline 9 & $\begin{array}{l}\text { Período } \\
\text { de pousio } \\
\text { (desativação } \\
\text { temporária da } \\
\text { produção da } \\
\text { área) }\end{array}$ & $\begin{array}{l}\text { Período de descanso da área } \\
\text { onde se cultiva espécies } \\
\text { leguminosas e gramíneas. }\end{array}$ & $\begin{array}{l}\text { Esta etapa dura de } 4-6 \text { meses e inicia-se após ser percebida uma } \\
\text { queda na produção da área. A incorporação das plantas no solo é } \\
\text { feita quando se tem uma biomassa vegetal elevada na área (inicia- } \\
\text { se a etapa 1). }\end{array}$ \\
\hline
\end{tabular}

Fonte: Alencar (2005).

As olerícolas utilizadas para cultivo nas áreas orgânicas são: abóbora, abobrinha, acelga, alface americana, alface crespa, alface lisa, alface roxa, alho-poró, batata-doce, berinjela, brócolis, cebola, cebolinha, cenoura, coentro, couve-flor, couve-folha, espinafre, hortelã, jiló, manjericão, pepino, pimentão, quiabo, rabanete, repolho, rúcula, salsa, tomate (em estufa) e vagem.
No sistema convencional de cultivo das olerícolas, as culturas multiplicadas predominantemente são o tomate, repolho e pimentão, principalmente pelo seu valor econômico. Estas áreas são caracterizadas pelo monocultivo, o uso da adubação química e o controle de pragas e doenças pelo uso de agrotóxicos (Tabela 4). 
Tabela 4. Sequência de etapas de manejo do solo e da cultura em sistemas de produções convencionais na Chapada da Ibiapaba

\begin{tabular}{|c|c|c|c|}
\hline Etapa & Atividade & Objetivo & Caracterização \\
\hline 1 & $\begin{array}{l}\text { Roçagem da vegetação } \\
\text { nativa }\end{array}$ & Cortar as plantas maiores & $\begin{array}{l}\text { O material vegetal derrubado é concentrado em } \\
\text { um local da área (coivaras) }\end{array}$ \\
\hline 2 & Queimada & $\begin{array}{l}\text { Limpar o terreno do material vegetal } \\
\text { originário da roçagem }\end{array}$ & $\begin{array}{l}\text { Coloca-se fogo no material vegetal concentrado } \\
\text { na área }\end{array}$ \\
\hline 3 & Aração & Revolvimento do solo da área & Realizado com auxílio do trator \\
\hline 4 & Calagem & $\begin{array}{l}\text { Melhorar o pH do solo para nível } \\
\text { satisfatório }\end{array}$ & $\begin{array}{l}\text { A calagem é feita com calcário dolomítico, } \\
\text { aplicando-se } 4-5 \text { toneladas/ha }\end{array}$ \\
\hline 5 & Abertura de covas & $\begin{array}{l}\text { Preparar o leito para o plantio das } \\
\text { mudas }\end{array}$ & Feita manualmente com auxílio da enxada \\
\hline 6 & Adubação de fundação & $\begin{array}{l}\text { Fornecer nutrientes para as futuras } \\
\text { plantas }\end{array}$ & $\begin{array}{l}\text { Usa-se esterco fresco ( } 2 \mathrm{~kg} / \text { cova), sendo irrigado } \\
\text { por } 15-20 \text { dias e, em seguida, aplica-se na cova } \\
\text { de } 50 \text { a } 100 \text { gramas da formulação NPK } 20-10-20\end{array}$ \\
\hline 7 & Plantio & $\begin{array}{l}\text { Multiplicar as plantas de melhor valor } \\
\text { comercial }\end{array}$ & $\begin{array}{l}\text { É realizado manualmente com as mudas } \\
\text { compradas em viveiros comerciais }\end{array}$ \\
\hline 8 & Adubação de manutenção & $\begin{array}{l}\text { Suplementar a adubação de fundação } \\
\text { para atender as necessidades das } \\
\text { plantas }\end{array}$ & $\begin{array}{l}\text { Realizada manualmente e a cada } 8 \text { a } 10 \text { dias, } \\
\text { colocando-se de } 20 \text { a } 25 \text { g da formulação } \\
\text { química NPK } 20-10-20 \text { por planta }\end{array}$ \\
\hline 9 & $\begin{array}{l}\text { Controle de pragas e } \\
\text { doenças }\end{array}$ & $\begin{array}{l}\text { Controlar a ocorrência de insetos e } \\
\text { doenças na plantação }\end{array}$ & Aplicam-se agrotóxicos com pulverizador costal \\
\hline 10 & Colheita & $\begin{array}{l}\text { Obter produção para venda nos } \\
\text { mercados consumidores da capital do } \\
\text { CE e estados do MA e PI }\end{array}$ & $\begin{array}{l}\text { Colheita realizada manualmente e sem respeitar } \\
\text { o período de carência dos agrotóxicos aplicados }\end{array}$ \\
\hline
\end{tabular}

Fonte: Alencar (2005).

\subsection{Diagnóstico regional dos sistemas agrícolas}

Foi realizado um diagnóstico regional qualitativo nas propriedades rurais no período de abril a junho de 2003, caracterizando os impactos sociais e ambientais da agricultura convencional e orgânica, seguindo-se critérios citados por Altieri (1989), Cardoso (1993), Mapurunga (2000) e Gomes (2002). As informações obtidas em campo são provenientes das entrevistas estruturadas de sete agricultores orgânicos e 21 agricultores convencionais de Guaraciaba do Norte e São Benedito, selecionados devido ao longo histórico de vivência e experiência com o sistema de produção adotado. As entrevistas foram realizadas por meio de conversa informal com o agricultor, utilizando-se um questionário orientativo, mas deixando o entrevistado a vontade para expor suas opiniões e experiências quanto ao sistema de cultivo adotado, aspectos socioeconômicos e culturais dos produtores e os aspectos ambientais da unidade produtiva. As perguntas foram feitas de forma aberta sem induzir as respostas com opções pré-definidas, deixando o entrevistado a vontade para expressar sua realidade.

Os objetivos destas entrevistas foram constatar o padrão regional de cultivo do solo, sejam nas modalidades orgânica ou convencional, funcionamento da cadeia produtiva, relações de trabalho, conhecimentos técnicos e empíricos, consciência ambiental, cultura popular, qualidade de vida e desenvolvimento humano.

\section{Resultados e discussão}

\subsection{Diagnóstico regional}

Os resultados obtidos das entrevistas foram trabalhados em função das diferenças apresentadas dentre os vários aspectos levantados nas propriedades orgânicas e convencionais, com o objetivo de se avaliar qualitativamente aspectos socioambientais dos sistemas de cultivo orgânico e convencional. 


\subsubsection{Sistema convencional de produção}

Os agricultores convencionais estabelecidos na região de Guaraciaba do Norte são caracterizados por possuírem, na sua maioria, área inferior a 50 ha e estarem classificados predominantemente, de acordo com o módulo fiscal, como minifúndios e pequenas propriedades (IPLANCE, 1998). A área realmente produtiva geralmente é inferior a 5 ha, utilizados para o cultivo de olerícolas com bons preços no mercado, tais como tomate e repolho.

O modelo típico de uso do solo pelos agricultores convencionais pode ser observado detalhadamente na Figura 2. Nesse sistema, o solo passa por um período de pousio, onde a vegetação natural entra em estágio inicial de regeneração. Após alguns meses, o agricultor faz a aração, abre as covas e aplica esterco de gado ou de frango não decomposto. Durante 15 a 30 dias, é realizada a irrigação das covas com o objetivo de promover condições favoráveis para as reações microbiológicas de decomposição. Neste estágio, a cova começa a receber o adubo químico (geralmente usa-se a fórmula NPK 20-10-20), difundido entre os agricultores como a ideal para o solo. Em seguida, o agricultor cultiva o tomate e o repolho. Após a retirada destas culturas, o agricultor passa a aproveitar o efeito residual da adubação com o plantio de batata-doce e, em seguida, realiza o consórcio da cultura da mandioca (comumente chamada de roça), milho e feijão. Após a colheita, o solo é deixado em pousio, começando-se um novo ciclo.

Geralmente, os agricultores utilizam áreas próprias. Entretanto, há casos de arrendamento da terra de forma diferente do tradicional. O arrendatário utiliza a terra na condição de que proceda as devidas adubações químicas e orgânicas, produzindo por um ou dois ciclos culturais (tomate, repolho ou pimentão), devolvendo, em seguida, ao proprietário. Nessa condição, o proprietário se satisfaz em produzir batata-doce e milho e feijão, posteriormente, na mesma área, aproveitando o efeito residual da adubação realizada pelo arrendatário. Este tipo de relacionamento de uso do solo cria a figura denominada na região de estrumador (arrendatário).

O agricultor utiliza recursos financeiros próprios para produzir no primeiro ciclo, sendo obrigado, na maioria das vezes, a assumir dívidas no comércio local, principalmente nas revendas de produtos agrícolas, através da relação insumo-produção, ou seja, as dívidas são quitadas com a colheita. Caso ocorra o fracasso na produção, novo crédito é estabelecido até que o agricultor consiga recursos suficientes para quitar as dívidas. Esta relação entre o comércio local e agricultores impulsiona o mercado local, porém, gera como consequência uma dependência permanente do agricultor.

Na região da Chapada da Ibiapaba, há aproximadamente 30 revendedoras de agrotóxicos,

Figura 2. Modelo rotacional típico de uso do solo pelos agricultores convencionais de olerícolas na Chapada da Ibiapaba (CE)

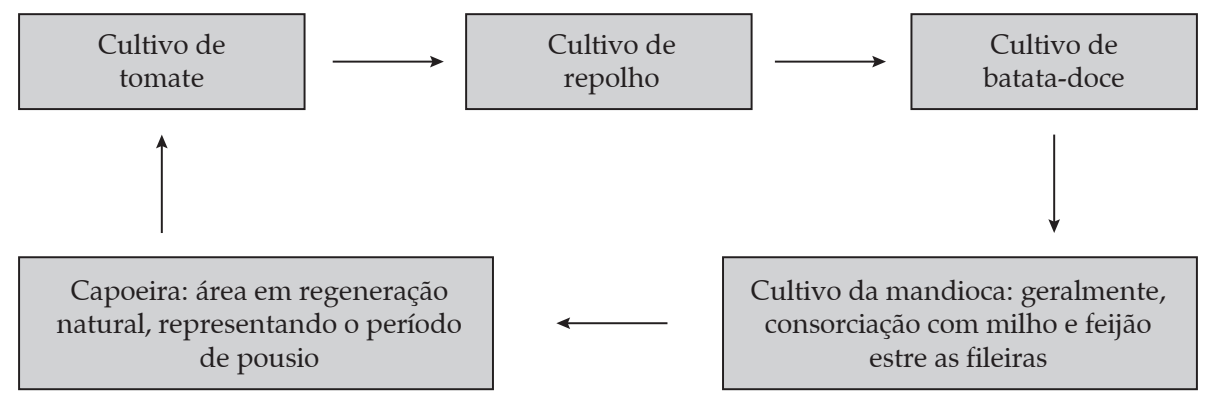

Fonte: Alencar (2005). 
Tabela 5. Principais agrotóxicos utilizados pelos agricultores convencionais do município de Guaraciaba do Norte (CE)

\begin{tabular}{|c|c|c|c|}
\hline $\begin{array}{l}\text { Nome } \\
\text { comercial }\end{array}$ & $\begin{array}{c}\text { Faixa indicativa } \\
\text { de cor }\end{array}$ & Toxicidade & Descrição \\
\hline Lannate & Vermelha & Extremamente tóxico & Inseticida do grupo dos carbamatos \\
\hline Elsan & Vermelha & Extremamente tóxico & Inseticida e acaricida sistêmico do grupo dos organofosforados \\
\hline Tamaron & Amarela & Muito tóxico & Inseticida e acaricida sistêmico do grupo dos organofosforados \\
\hline Talcord & Azul & Moderadamente tóxico & Inseticida do grupo dos Piretróides \\
\hline Karate & Azul & Moderadamente tóxico & Inseticida do grupo dos Piretróides \\
\hline Thiobel & Azul & Moderadamente tóxico & Inseticida do grupo dos tiocarbamato \\
\hline Decis & Azul & Moderadamente tóxico & Inseticida e acaricida do grupo dos Piretróides \\
\hline Curacron & Azul & Moderadamente tóxico & Inseticida e acaricida do grupo dos organofosforados \\
\hline Orthene & Verde & Pouco tóxico & Inseticida do grupo dos organofosforados \\
\hline
\end{tabular}

Fonte: Alencar (2005).

grande parte voltada para a cultura do tomate, principal cultura e grande consumidora de pesticidas agrícolas (SEMACE, 2004). Em Guaraciaba do Norte, constata-se, no mercado de agrotóxico, o envolvimento de agrônomos na venda e divulgação dos produtos, inclusive com o deslocamento diretamente à propriedade, no intuito de oferecer gratuitamente "assistência técnica", porém, vinculada à venda de agrotóxicos. $\mathrm{Na}$ Tabela 5 são apresentados os agrotóxicos mais comumente utilizados pelos agricultores de Guaraciaba do Norte e o grau de toxicidade dos mesmos.

A incorreta utilização destes compostos pode ser constatada pela ausência de uso de proteção durante a aplicação do produto. É comum afirmações do tipo: “...os venenos de hoje em dia são muito fracos, bate na praga e não mata, mesmo preparando ele mais forte. Já pulverizei muito e nunca senti nada". Em geral, em grande parte dos casos, as embalagens dos produtos químicos não têm o destino adequado, sendo, muitas vezes, utilizadas para enfeitar as estacas do tutoramento do tomateiro ou, então, jogadas nas entrelinhas das culturas.

O uso de agrotóxicos ocorre sem conhecimento técnico necessário das consequências relativas aos excessos praticados, bem como pela falta de uso de equipamentos de proteção individual.
O uso exagerado de agrotóxicos nas lavouras pode ser constatado em dados de pesquisa que afirmam que o consumo médio de agrotóxico no Brasil é de 1,5 kg/ha/ano, sendo a fruticultura consumidora de $8 \mathrm{~kg} / \mathrm{ha} / \mathrm{ano}$ e a horticultura chegando a $10 \mathrm{~kg} / \mathrm{ha} / \mathrm{ano}$, o que coloca o País como o terceiro maior consumidor de agrotóxicos do mundo, perdendo apenas para os Estados Unidos e para o Japão (PONTE, 1998; JORNAL O POVO, 2005). Quando se analisa a região da Chapada da Ibiapaba, constata-se que a situação é alarmante. A utilização de inseticidas organofosforados, carbamatos, piretróides e nicotinóides e fungicidas protetores e sistêmicos tem aumentado a preocupação com relação à poluição do lençol freático, contaminação de solos, existência de resíduos químicos em alimentos, contaminação de água potável, aumento dos casos de suicídios e intoxicações por substâncias químicas e poluentes orgânicos persistentes (MMA, 2003).

Este quadro é agravado pela falta de compromisso do agricultor com relação ao tempo de carência dos produtos, o que pode ser verificado por ocasião da colheita, constatando-se resíduos recém-aplicados, principalmente o tomate.

O destino da produção do agricultor tem sido a venda diretamente na Central de Abastecimento (Ceasa) do município de Tianguá (quando os agricultores possuem recursos financeiros para o 
transporte) ou a venda para atravessadores que adquirem os produtos diretamente na propriedade, praticando normalmente preços baixos e geralmente após a venda do produto, situação esta muitas vezes acompanhada pelo calote do atravessador. O lucro pode enriquecer o produtor (quando a cotação do produto está em alta) ou ser muito pequeno, pois prejuízos ocasionados por pragas e doenças ou preços baixos podem acontecer, deixando-o endividado. Pode-se afirmar que o mercado e as condições ambientais ditam o futuro do agricultor.

A relação dos agricultores com os recursos naturais baseia-se na dependência do meio ambiente: retiram lenha seca das matas para usar no fogão; utilizam e sabem da importância do rio para a sua sobrevivência; sabem que o desmatamento traz problemas para a agricultura (pragas e doenças); cultivam a roça e legumes, armazenando a produção para o sustento da família; enterram o lixo produzido pela família em barreiros (buraco no solo); acreditam na influência da lua na produção (plantar em lua minguante é produção baixa) e mantêm relação de solidariedade na comunidade. Além disso, o agricultor se preocupa com a família, fazendo uma poupança pelo aumento do rebanho de animais domésticos de criação (geralmente de gado). Quando as dificuldades aumentam, o agricultor vende alguns para saldar suas dívidas.

\subsubsection{Sistema orgânico de produção}

$\mathrm{Na}$ Chapada da Ibiapaba esse paradigma surgiu como resposta à agressão ambiental ocasionada pelos agrotóxicos utilizados na agricultura convencional. Por ser uma região onde predomina a produção de hortifrutigranjeiros, a região tornou-se foco de discussão de técnicos e de denúncias da imprensa pelo fato de os agrotóxicos estarem contaminando os próprios agricultores, além dos produtos.

Em 1997, foi fundada a Adao (Associação para o Desenvolvimento da Agropecuária Orgânica), uma organização sem fins lucrativos, tendo como finalidade a fomentação da produção e do con- sumo de produtos orgânicos. A Adao é uma associação de consumidores de Fortaleza (CE) que, conscientes da salubridade da alimentação orgânica, financiam agricultores associados na produção orgânica nas áreas certificadas. A comprovação da origem dos produtos orgânicos é dada pela confiança da relação agricultor-consumidor, devido à inviabilidade econômica (elevação de custos de produção) para aquisição do selo orgânico da certificadora IBD. Atualmente, são 460 consumidores associados à Adao, que, por meio de um valor pago mensalmente, recebem semanalmente uma cesta básica mínima (CBM) composta por 10 variedades de olerícolas ou da escolha livre dos produtos em dois pontos de distribuição em Fortaleza.

A figura do atravessador não existe nesta modalidade de relação produtor-consumidor, pois a ênfase no processo é dada ao comércio justo. De um lado, têm-se os produtores que ficam responsáveis em cultivar as olerícolas e frutíferas de interesse dos associados e, do outro lado, existem os consumidores que pagam para que o produtor produza organicamente.

Anualmente, a Adao realiza assembleia geral com presença de todos os associados (produtores e consumidores) com a finalidade de definir o calendário agrícola do ano, determinando a relação de produtos que os agricultores deverão produzir mensalmente e os respectivos valores a serem pagos pelo produto. O interessante nesta assembleia é que o distanciamento existente na relação produtor-consumidor no modelo de produção convencional não existe aqui. Os consumidores têm contato direto com os produtores e existe a responsabilidade ética de ambas as partes, com o objetivo de produzir com qualidade.

A receita proveniente da arrecadação mensal realizada pela Adao junto aos consumidores é destinada ao pagamento do transporte dos produtos e da administração da entidade, sendo o restante utilizado para custeio dos produtores orgânicos. Atualmente são quatro produtores orgânicos da Adao situados em Guaraciaba do Norte, abrangendo três olerícultores e um fruticultor. Todos os produtores recebem o preço justo 
pelo que produzem, satisfazendo os preceitos de qualidade de vida de sua família, assim como permitem que os empregados contratados sejam mais bem remunerados.

As propriedades orgânicas diferenciam-se em vários pontos da propriedade convencional, tais como: o planejamento da propriedade; a diversificação e rotação das culturas; o manejo do solo; a interação com o meio ambiente (conhecimento holístico do meio); o baixo custo energético dos produtos cultivados e a qualidade de vida dos agricultores devido à não utilização de agrotóxicos (Tabela 6).

A baixa dependência de insumos externos das propriedades orgânicas faz com que estas funcionem como unidades quase autônomas, o que pode ser atribuído à forma organizada e planejada de uso dos recursos existentes na propriedade (sistema integrado de produção).

As propriedades orgânicas são caracterizadas pelo planejamento da área. A base da organização são os conceitos agroecológicos aplicados no manejo do solo e das culturas. Tudo é organi- zado tentando-se imitar a natureza; o agricultor está presente como um administrador ecológico da produção. A propriedade é fragmentada em glebas limitadas por cordões de vegetação de gramíneas ou quebra-ventos de árvores, servindo, inclusive, como refúgios para insetos benéficos, controle da erosão e áreas de ciclagem de nutrientes.

Os canteiros construídos são adubados organicamente na fundação com composto produzido na propriedade, constituído de esterco de gado, bagaço de cana, fosfato de rocha, MB-4, EM-4 e melaço, tendo o processo de compostagem duração de 70-80 dias. A composição química do composto orgânico utilizado nas propriedades é apresentada na Tabela 7. As diferenças em nutrientes entre os compostos das quatro áreas são atribuídas aos diferentes materiais utilizados na preparação dos mesmos.

As culturas implantadas em cada horta só permanecem um ciclo, sendo sucedidas por outra cultura de família botânica diferente. Neste modelo, constatam-se diversas hortas espalhadas

Tabela 6. Diferenças entre os sistemas de cultivo orgânico e convencional na Chapada da Ibiapaba

\begin{tabular}{l|l|l}
\hline \multicolumn{1}{c|}{ Característica } & \multicolumn{1}{c}{ Cultivo Orgânico } & \multicolumn{1}{c}{ Cultivo Convencional } \\
\hline Planejamento da propriedade & $\begin{array}{l}\text { Realizado com enfoque da manutenção da sus- } \\
\text { tentabilidade da produção }\end{array}$ & Não existe planejamento \\
\hline Manejo do solo & $\begin{array}{l}\text { Visa elevar os teores de matéria orgânica do solo } \\
\text { e equilíbrio com o meio ambiente }\end{array}$ & $\begin{array}{l}\text { Desvinculação com a limitação da } \\
\text { fertilidade do solo. Exaustão do solo }\end{array}$ \\
\hline Culturas implantadas & Diversificação e rotação de culturas & Monoculturas \\
\hline Relação com o meio ambiente & Dependência contínua do meio ambiente & Relação de dominação \\
\hline Dependência de insumos externos & Mínima & Total \\
\hline Mercado & Restrito & Amplo \\
\hline Qualidade dos produtos & Preferência dos consumidores esclarecidos & $\begin{array}{l}\text { De ampla aceitação devido ao preço } \\
\text { e oferta do produto. }\end{array}$ \\
\hline
\end{tabular}

Fonte: Alencar (2005).

Tabela 7. Composição química dos compostos utilizados nas propriedades orgânicas das áreas 1, 2, 3 e 4 no município de Guaraciaba do Norte (CE)

\begin{tabular}{|c|c|c|c|c|c|c|c|c|c|c|c|c|}
\hline Área & $\mathbf{N}$ & $\mathbf{P}$ & K & $\mathrm{Ca}$ & $\mathrm{Mg}$ & C Total & MO & Rel. C/N & $\mathrm{Fe}$ & $\mathrm{Zn}$ & Mn & $\mathrm{Cu}$ \\
\hline & & -1--- & -1---- & $-\%$ & -1---. & 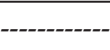 & ----- & & \multicolumn{4}{|c|}{ 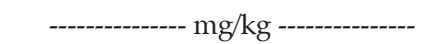 } \\
\hline 1 & 0,85 & 0,34 & 1,64 & 0,75 & 0,49 & 20,10 & 34,66 & 23,72 & 3394,13 & 48,23 & 85,93 & 7,95 \\
\hline 2 & 1,08 & 0,38 & 1,01 & 2,32 & 0,53 & 22,67 & 39,09 & 20,99 & 4872,70 & 104,30 & 287,97 & 10,80 \\
\hline 3 e 4 & 1,15 & 0,28 & 1,26 & 0,75 & 0,46 & 22,96 & 39,60 & 19,92 & 376,60 & 34,30 & 93,63 & 9,87 \\
\hline
\end{tabular}

Fonte: Alencar (2005). 
na gleba, diversificadas nas culturas e em contínuo processo de rotação, o que beneficia o solo e dificulta o surgimento de pragas e doenças.

Nas bordas e interior das glebas é comum a presença de plantas companheiras ou repelentes (cravo de defunto, urtiga etc.) que favorecem o controle de pragas. A presença de mata nativa próxima das áreas de produção orgânica permite que haja um equilíbrio ecológico do ambiente, estando as pragas apenas presentes de forma a causar uma pequena e tolerável perda na produção.

As medidas de controle de pragas e doenças realizadas pelos agricultores orgânicos são provenientes do conhecimento dos produtos naturais obtidos de plantas encontradas na propriedade ou na mata (nim, urtiga, mandioca, entre outras), cujo extrato diluído em proporções adequadas em água é utilizado no combate a pragas e doenças.

A água que abastece a propriedade orgânica é proveniente de poços construídos às margens do riacho Cachoeirinha, denominados poço amazona. Este tipo de poço permite uma melhor qualidade de água para irrigação das olerícolas, devido ao fato de que a água contida dentro do poço é proveniente do lençol freático que abastece o riacho. Importante ressaltar que o riacho citado atravessa várias propriedades convencionais, o que se caracteriza como foco contaminante de suas águas e, por consequência, das culturas por elas irrigadas.

A análise de água procedida nos poços amazonas (utilizados para irrigar as olerícolas orgânicas) e no riacho cachoeirinha são apresentados na Tabela 8. As quatro áreas de estudo apresentaram água utilizada na irrigação das culturas com classificação $C_{1} S_{1}$, com exceção do poço da área 2 , que indicou $C_{2} S_{1}$, as quais são consideradas de boa qualidade, podendo ser utilizadas na maioria dos solos com baixo perigo de salinização e sodificação.

O manejo do solo é um componente importante, senão o principal, nas propriedades orgânicas. Nas áreas em produção, após alguns anos (3-4), o agricultor constata a redução da produção de olerícolas, o que leva ao pousio por um tempo de seis meses, onde será feita adubação verde com leguminosas e gramíneas (aproximadamente 23 espécies) com posterior incorporação ao solo (Tabela 9). A adubação verde forma uma ciclagem de nutrientes mais eficiente, com a elevação do teor de matéria orgânica no solo e o enriquecimento com nitrogênio (fixação biológica), possibilitando a recuperação do solo (SOUZA e RESENDE, 2003).

Na Tabela 10, é apresentada a composição química média do substrato da adubação verde realizada, constatando-se valores elevados de matéria orgânica e baixa relação $\mathrm{C} / \mathrm{N}$, potencializando a mineralização rápida do material aplicado. Os macro e micronutrientes presentes no substrato contribuem para a elevação da fertilidade dos solos de sistema de cultivo orgânico. A recuperação de solos exauridos pelo cultivo intensivo através do uso de plantas leguminosas e forrageiras é confirmada por vários autores (PEREIRA, 1999; ZAMBERLAM e FRONCHETI, 2001; PENTEADO, 2003; SOUZA e RESENDE, 2003).

Tabela 8. Análise da água dos poços amazonas e do rio cachoeirinha em áreas das propriedades orgânicas

\begin{tabular}{|c|c|c|c|c|c|c|c|c|c|c|c|c|c|c|c|}
\hline \multirow{3}{*}{ Área } & \multirow{3}{*}{ Local } & \multicolumn{5}{|c|}{ Cátions } & \multicolumn{5}{|c|}{ Ânions } & \multirow{2}{*}{$\mathrm{CE}$} & \multirow{3}{*}{ RAS } & \multirow{3}{*}{$\mathrm{pH}$} & \multirow{2}{*}{ SD } \\
\hline & & $\mathrm{Ca} a^{+2}$ & $\mathrm{Mg}^{+2}$ & $N a^{+}$ & $K^{+}$ & $S$ & $\mathrm{Cl}^{-}$ & $\mathrm{SO}_{4}^{-2}$ & $\mathrm{HCO}_{3}^{-}$ & $\mathrm{CO}_{3}^{-2}$ & $S$ & & & & \\
\hline & & \multicolumn{10}{|c|}{ 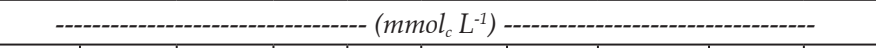 } & $d S m^{-1}$ & & & $m g L^{-1}$ \\
\hline \multirow{2}{*}{1} & poço & 0,5 & 0,8 & 0,5 & 0,1 & 1,9 & 1,4 & - & 0,4 & - & 1,8 & 0,19 & 0,63 & 5,6 & 190 \\
\hline & riacho & 0,3 & 0,2 & 0,2 & 0,1 & 0,8 & 0,4 & - & 0,3 & - & 0,7 & 0,07 & 0,45 & 6,0 & 70 \\
\hline \multirow{2}{*}{2} & poço & 0,8 & 0,8 & 1,1 & 0,6 & 3,3 & 3,0 & - & 0,1 & - & 3,1 & 0,33 & 1,28 & 5,0 & 330 \\
\hline & riacho & 0,2 & 0,3 & 0,3 & 0,05 & 0,85 & 0,6 & - & 0,2 & - & 0,80 & 0,08 & 0,50 & 5,8 & 80 \\
\hline 3 e $4^{*}$ & riacho & 0,2 & 0,2 & 0,3 & 0,05 & 0,75 & 0,6 & - & 0,2 & - & 0,8 & 0,07 & 0,60 & 5,3 & 70 \\
\hline
\end{tabular}

Legenda: SD - Sólidos dissolvidos; RAS - Razão de adsorção de sódio; * áreas sem poço amazonas.

Fonte: Alencar (2005). 
Tabela 9. Relação de espécies e quantidades de sementes que compõem o coquetel de leguminosas e gramíneas preparadas nas propriedades orgânicas de Guaraciaba do Norte (CE)

\begin{tabular}{|c|c|c|c|c|c|}
\hline Espécies & $\begin{array}{c}\text { Quantidade de } \\
\text { sementes (kg/ha) }\end{array}$ & Espécies & $\begin{array}{c}\text { Quantidade de } \\
\text { sementes }(\mathrm{kg} / \mathrm{ha})\end{array}$ & Espécies & $\begin{array}{c}\text { Quantidade de } \\
\text { sementes }(\mathrm{kg} / \mathrm{ha})\end{array}$ \\
\hline Feijão de porco & 12 & Mucuna & 30 & Kudzu & 5 \\
\hline Guandu & 4 & Crotalária & 4 & Fava & 4 \\
\hline Mamona & 4 & Soja & 5 & Feijão de corda & 8 \\
\hline Abóbora & 1 & Lab-lab & 8 & Leucena & 3 \\
\hline Milho & 12 & Tefrosia & 1 & Feijão bravo & 2 \\
\hline Milheto & 2 & Amaranto & 1 & Sorgo & 3 \\
\hline Dente de burro & 1 & Girassol & 10 & Calopogônio & 2 \\
\hline Feijão de rolinha & 1 & Sorgo & 3 & Total & 126 \\
\hline
\end{tabular}

Fonte: Alencar (2005).

Tabela 10. Análise química do substrato da adubação verde em propriedades orgânicas na Chapada da Ibiapaba (valores médios)

\begin{tabular}{|c|c|c|c|c|c|c|c|c|c|c|c|}
\hline $\mathrm{Ca}$ & $\mathrm{Mg}$ & $\mathbf{P}$ & $\mathrm{K}$ & $\mathbf{N}$ & MO & COT & \multirow{2}{*}{$\begin{array}{c}\text { Relação } \\
\text { C/N }\end{array}$} & Mn & $\mathrm{Zn}$ & $\mathrm{Cu}$ & $\mathrm{Fe}$ \\
\hline & & & $\%$ & & & & & \multicolumn{4}{|c|}{$\mathrm{mg} / \mathrm{kg}$} \\
\hline 1,8 & 0,25 & 0,18 & 0,45 & 1,80 & 73,60 & 42,69 & 23,71 & 17,0 & 22,8 & 16,30 & 179,92 \\
\hline
\end{tabular}

Fonte: Alencar (2005).

Esta forma de interagir com o meio ambiente faz do agricultor orgânico um propagador de modelo de produção, atraindo o interesse e a simpatia de muitos agricultores convencionais que não conseguem realizar a ruptura com o modelo convencional. Em muitos aspectos os agricultores orgânicos se assemelham aos agricultores convencionais: tradições, influência da lua, destino do lixo, poupança feita com animais, solidariedade entre vizinhos e comunidade. Assim, não existe um distanciamento cultural entre agricultores orgânicos e convencionais, o que facilita a permeabilidade do paradigma orgânico na agricultura convencional.

Esse modelo de agricultura orgânica tem uma relevância maior quando se tem as suas bases construídas conforme preceitos científicos da agroecologia, permitindo-se ter uma visão geral do sistema atrelada às informações científicas, conforme comentado por Aquino e Assis (2007).

Além da Adao, na região da Chapada da Ibiapaba, surgiu outra associação, a Apoi (Associação dos Produtores Orgânicos da Ibiapaba), criada em 2001, formada por 18 famí- lias de agricultores de Ubajara, Ibiapina, São Benedito e Carnaubal, que plantam cerca de 20 tipos de olerícolas. A comercialização é com o Grupo de Supermercados Pão de Açúcar, em Fortaleza. Isso mostra que a agricultura orgânica está em ascensão na região e mudando a forma de pensar e produzir o alimento.

\subsection{Análise econômica da produção orgânica x convencional}

Os resultados econômicos das propriedades orgânicas e das propriedades convencionais são bastante diferenciados (Tabela 11).

Mesmo o cultivo convencional apresentando resultados financeiros superiores em relação ao orgânico, para a cultura do tomate, esta é uma situação que acontece apenas na entressafra, quando os preços dos produtos são elevados. Entretanto, devido às quedas de produção e preços baixos fora da entressafra, os agricultores convencionais frequentemente têm o lucro reduzido até 1/3 do que é mostrado na Tabela 11, e muitas vezes ficam endividados. $\mathrm{O}$ agricultor orgânico 
Tabela 11. Custo de produção, receita e lucro médio por safra dos agricultores orgânicos e convencionais do município de Guaraciaba do Norte $(\mathrm{CE})^{*}$

\begin{tabular}{ccccccc}
\hline $\begin{array}{c}\text { Sistema de } \\
\text { cultivo }\end{array}$ & $\begin{array}{c}\text { Espécies } \\
\text { cultivadas }\end{array}$ & $\begin{array}{c}\text { Produtividade } \\
\text { (ton/ha) }\end{array}$ & $\begin{array}{c}\text { Custo de produção } \\
\text { (R\$) }\end{array}$ & $\begin{array}{c}\text { Receita } \\
\text { (R\$) }\end{array}$ & $\begin{array}{c}\text { Lucro } \\
\text { (R\$) }\end{array}$ & $\begin{array}{c}\text { Lucro mensal } \\
\text { (R\$) }\end{array}$ \\
\hline Orgânico & Olerícolas variadas & 12 & $3.500,00$ & $5.500,00$ & $8.000,00^{* *}$ & $2.000,00$ \\
Convencional & repolho & 55 & $12.000,00$ & $16.500,00$ & $4.500,00^{* *}$ & $1.125,00$ \\
Convencional & tomate & $40-50$ & $25.000,00$ & $40.000,00$ & $15.000,00^{* *}$ & $3.750,00$ \\
Convencional & pimentão & 24 & $6.000,00$ & $14.000,00$ & $8.000,00^{* *}$ & $2.000,00$ \\
\hline
\end{tabular}

* Informações obtidas diretamente com os agricultores, representando valores médios regionais.

** Lucro referente ao ciclo cultural de quatro meses (plantio até a colheita completa).

Fonte: Mapurunga (2000) e Alencar (2005).

tem lucro garantido devido à maior autonomia e diversidade de produção, o que permite a estabilidade econômica do empreendimento.

A rentabilidade superior dos cultivos orgânicos em relação aos convencionais é atribuída aos baixos custos de produção e aos preços estáveis (cotações em patamares elevados) dos produtos orgânicos no mercado. Essa situação contribui para a elevação da qualidade de vida dos agricultores orgânicos e a manutenção de um modelo produtivo em harmonia com o meio ambiente, contribuindo para sua capitalização e inserção numa economia de mercado mais justa (PEREIRA, 1999; MAPURUNGA, 2000; DAROUT, 2002; MAZZOLENI e NOGUEIRA, 2006).

\section{Mercado de produtos orgânicos}

O levantamento realizado junto a consumidores de produtos hortifrutigranjeiros em supermercados de Fortaleza (CE) por Mapurunga (2000) mostrou a preferência pelo consumo de produtos cultivados sem agrotóxicos (Tabela 12).

Entretanto, quando se aborda o aspecto de quanto o consumidor pagaria a mais por um produto orgânico, houve uma diferenciação conforme o poder aquisitivo da família. Isso demonstra a necessidade de redução dos custos de produção dos sistemas orgânicos para viabilizar o acesso universal ao produto.

Tabela 12. Disposição a pagar por produtos orgânicos pelos consumidores de Fortaleza (CE)

\begin{tabular}{cccc}
\hline $\begin{array}{c}\text { Entrevistados* } \\
(\%)\end{array}$ & $\begin{array}{c}\text { Renda familiar } \\
\text { (salário mínimo) }\end{array}$ & Grau de instrução & $\begin{array}{c}\text { Disposição a pagar** } \\
(\%)\end{array}$ \\
\hline 39 & $0-2$ & Primário & 0 \\
15 & $2-5$ & Primário & 0 \\
11 & $2-5$ & $2^{\circ}$ grau e superior & Até 25 \\
3 & $5-10$ & Primário & Até 25 \\
6 & $5-10$ & $2^{\circ}$ grau e superior & Até 25 \\
1 & $>10$ & Primário & Até 25 \\
5 & $>10$ & $2^{\circ}$ grau e superior & Até 50 \\
\hline
\end{tabular}

* Amostragem de 100 consumidores.

** Quanto o consumidor pagaria a mais pelo produto orgânico em relação ao convencional.

Fonte: Mapurunga (2000). 
A consciência ecológica observada localmente, fruto principalmente do trabalho divulgador dos meios de comunicação de massa e pela busca de uma alimentação saudável e natural sem agrotóxico, pode ser extrapolada para a sociedade brasileira. Segundo pesquisa do Ibope (2005), realizada no período de 8 a 13 de maio de 2005, versando sobre o tema "Política Ambiental", onde foram entrevistados 2.000 indivíduos nas cinco regiões brasileiras, foi constatado que $68 \%$ dos entrevistados estariam dispostos a pagar mais caro por um produto que não polui o meio ambiente, opinião que abrange todas as classes sociais.

A qualidade dos produtos orgânicos é um fator impulsionador da preferência dos consumidores. Smith (1993) publicou uma pesquisa de qualidade nutricional dos alimentos orgânicos e convencionais, comparando-os quanto aos teores de macro e micronutrientes e metais pesados. Neste trabalho, foi comprovada a superioridade em teores de minerais e menores teores de metais pesados dos alimentos orgânicos em relação aos convencionais.

Mesmo com a preferência dos consumidores pela compra de produtos orgânicos, seria importante ressaltar que esse comércio necessita de maior fiscalização para garantir a qualidade e procedência dos produtos. Mazzoleni e Oliveira (2010) constataram a importância da certificação para se atingir esse objetivo, além de ser um fator impulsionador para a implementação das inovações tecnológicas neste sistema produtivo.

\section{Conclusão}

As bases de produção orgânica de olerícolas nas propriedades pesquisadas no município de Guaraciaba do Norte e São Benedito (CE) indicam a melhoria na qualidade de vida das famílias envolvidas na atividade. Essa situação é proporcionada pelas formas de uso dos bens ambientais nas propriedades orgânicas, alimentação saudável, trabalho em ambiente salubre e melhor retorno financeiro da produção. Na produção convencional, é constatado o comprometimento da qualidade de vida do agricultor devido ao uso exagerado e inadequado de agrotóxicos e o descompromisso na manutenção da fertilidade do solo. No aspecto do meio ambiente, os sistemas orgânicos geram impactos ambientais pouco significativos, enquanto que, no convencional, esses impactos são mais evidentes, principalmente quanto à qualidade dos produtos produzidos e comercializados com provável presença de resíduos de agrotóxicos.

\section{Referências bibliográficas}

AAO (Associação de Agricultura Orgânica). Disponível em: <http://www.aao.org.br>. Acesso em 10 mar. 2005.

AMBIENTE BRASIL. Disponível em: < http://www. ambientebrasil.com.br>. Acesso em 5 de fev. de 2005.

ALENCAR, G.V. Caracterização socio-ambiental de sistemas de cultivo orgânico e convencional na Chapada da Ibiapaba, Ceará. 2005. Tese (Doutorado em Agronomia/Solos e Nutrição de Plantas) - Universidade Federal de Viçosa, 206p.

ALTIERI, M. A. Agroecologia: as bases científicas da agricultura alternativa. Trad. de Patrícia Vaz. Rio de Janeiro, Agropecuária, 1989. 240p.

APEX (Agência de Promoção de Exportadores do Brasil). Disponível em: <http://www.apexbrasil.com.br>. Acesso em 20 mar. 2005.

APRECE - ASSOCIAÇÃO DOS MUNICÍPIOS DO ESTADO DO CEARÁ. Disponível em: < http://www. aprece.org.br/site/?prefeitura $=74 \&$ acao $=$ conheca omunicipio $>$. Acesso em: 10 jun. 2012.

AQUINO, A. M. e ASSIS, R.L. Agricultura orgânica em áreas urbanas e periurbanas com base na agroecologia. Ambiente E Sociedade, Campinas, v. 1, p. 137-150, 2007.

ASSIS, R. L., AREZZO, D. C. e De POLLI, H. Consumo de produtos da agricultura orgânica no Estado do Rio de Janeiro. Revista de Administração, v. 1, p. 84-89, 1995.

CARDOSO, I. M. Percepção e uso, por pequenos agricultores, dos ambientes de uma microbacia no município de Ervália-MG. Dissertação (Mestrado) - Viçosa, UFV, 1993.

CERVEIRA, R. e CASTRO, M.C. Consumidores de produtos orgânicos da cidade de São Paulo: características de um padrão de consumo. Informações Econômicas, v. 12, p. 7-20, 1999. 
COGERH - Companhia de Gestão de Recursos Hidrícos do Estado do Ceará. Disponível em: <http:// portal.cogerh.com.br/>. Acesso em: 16 jun. 2012.

DAROLT, M. R. Agricultura orgânica: inventando o futuro. IAPAR, Londrina, 2002. 250p.

EHLERS, E. Agricultura sustentável: origem e perspectivas de um novo paradigma. 2. ed. Guaíba, Agropecuária, 1999. 157p.

EMBRAPA, Centro Nacional de Pesquisa de Solos. Sistema brasileiro de classificação de solos. Rio de Janeiro, EMBRAPA Solos, 1999. 412p.

EMBRAPA - Agroindústria Tropical. Impacto do Manejo Integrado de Pragas na Redução do Uso de Agrotóxicos em Cultivo Protegido do Tomateiro. Comunicado Técnico. Fortaleza, 2011. 5 p.

FUNCEME. Dados pluviométricos. 2003. (Boletim digital)

GLIESSMAN, S. R. Agroecologia: processos ecológicos em agricultura sustentável. Trad. Maria José Guazzelli. Porto Alegre, UFRGS, 2000. 653p.

GOMES, F. H. Caracterização de solos de manguezais e de restinga no município de Ilhéus-Bahia. Dissertação (Mestrado) Viçosa, UFV, 2002.

IBGE - INSTITUTO BRASILEIRO DE GEOGRAFIA E ESTATÍSTICA. Censo Agropecuário 2006. Disponível em: <www.ibge.gov.br>. Acesso em: 10 jun. 2012.

IBGE - INSTITUTO BRASILEIRO DE GEOGRAFIA E ESTATÍSTICA. Censo de 2010. Disponível em: <http:// www.ibge.gov.br/cidadesat/topwindow.htm?1>. Acesso em: 10 jun. 2012.

ICID. Desenvolvimento e meio ambiente no semi-árido. Fundação Grupo Esquel Brasil, Brasília, 1992. 166p.

IBOPE. Opinião Pública: Consumidor se dispõe a pagar mais por produtos anti-poluente.Disponível em: <http://www.ibope.com.br/calandraWeb/servlet/ Calandra Redirect? temp $=5 \& p r o j=$ PortalIBOPE\&pu $\mathrm{b}=\mathrm{T} \& \mathrm{db}=$ caldb\&comp $=$ Opinião + Públi-ca\&docid $=$ 5A461A5 09C35E9F2 83256EA500620A03>. Acesso em: 10 mar. 2005.

IPECE - INSTITUTO DE PESQUISA E ESTRATÉGIA ECONÔMICA DO CEARÁ. Perfil Básico Municipal 2011 - Guaraciaba do Norte. Fortaleza, Secretaria do Planejamento e Gestão do Estado do Ceará. Disponível em: <http://www.ipece.ce.gov.br/publicacoes/perfil basico/pbm-2011/Guaraciaba_do_Norte.pdf $>$. Acesso em: 10 jun. 2012.
IPLANCE. Perfil básico municipal - Guaraciaba do Norte. Fortaleza, Secretaria do Planejamento e Coordenação do Estado do Ceará, 1998. 44p.

JORNAL O POVO. Disponível em: <http://www. noolhar.com/opovo/ceara/162629. html >. Acesso em: 12 maio 2005.

LIMA, H. V. Influência dos sistemas de cultivo orgânico $e$ convencional de algodão sobre a qualidade do solo no município de Tauá-CE. Dissertação (Mestrado) Universidade Federal do Ceará, 2001.

LIMA, P. B. F. e JOCA, T. H. P. Manejo ecológico do algodoeiro mocó (Gossypium hirsutum Marie Galante Hutch.) visando à convivência produtiva com o bicudo (Anthonomus grandis Boheman), ESPLAR. Fortaleza, 1990. 20p (Projeto de Pesquisa)

MAPA - MINISTÉRIO DA AGRICULTURA, PECUÁRIA E ABASTECIMENTO. Instrução Normativa № 64, de 18 de dezembro de 2008. Disponível em: $<$ http://extranet.agricultura.gov.br/sislegis-consulta/ consultarLegislacao.do >. Acesso em: 10 jun. 2012.

MAPURUNGA, L. F. Análise da sustentabilidade da agricultura orgânica: um estudo de caso. Dissertação (Mestrado) Fortaleza, UFC, 2000.

MAZZOLENI, E. M. e NOGUEIRA, J. M. N. Agricultura orgânica: características básicas do seu produtor. RESR, Brasília, v. 44, p. 263-293, 2006.

MAZZOLENI, E. M. e OLIVEIRA, L. G. Inovação Tecnológica na Agricultura Orgânica: estudo de caso da certificação do processamento pós-colheita. RESR, Brasília, 48, p. 567-586, 2010.

MMA - Ministério do Meio Ambiente. Perfil nacional da gestão de substâncias químicas - PNGSQ. Programa de proteção e melhoria na qualidade ambiental. Brasília, v. 3, p. 68-73, 2003.

MIYASAKA, S., NAKAMURA, Y. e OKAMOTO, H. Agricultura natural. 2. ed. Cuiabá, SEBRAE/MT, 1997.

PENTEADO, S. R. Introdução à agricultura orgânica. Viçosa, Aprenda Fácil, 2003. 235p.

PEREIRA, J.C. Roland Ristow: uma contribuição ao estudo da agricultura sustentável. Dissertação (Mestrado) UFSC, Florianópolis, 1999. 111p.

PRIMAVESI, A. A alimentação no século XXI. In: Congresso Brasileiro de Horticultura Orgânica, Natural, Ecológica e Biodinâmica, 1, Piracicaba, 2001. Anais. Botucatu, Livraria e Editora Agroecológica, 2001. p. 7-12. 
PONTE, J. J. Leandro, cancer e agrotóxicos. Revista Proteção, n. 84, p. 53, 1998.

ROBERTS, B. The quest for sustainable agriculture and land use. Austrália, University of New South Wales Press, 1995.

ROSSET, P. A revolução está ficando verde. Ijuí, Unijuí, 1995.

SEMACE. Programa de Controle e Fiscalização de Agrotóxicos. Disponível em: <http://www.semace. ce.gov.br/programas/programa.asp? $\mathrm{cd}=45>$. Acesso em: 19 set. 2004.

SMITH, B. L. Organic Foods vs Supermarket Foods: Element Levels. Journal of Applied Nutrition, 45-1, 1993.
SOUZA, J. L. Manejo orgânico de solos: a experiência da Emcaper. Viçosa, SBCS, v. 4, p. 13-16, 2000. (Boletim Informativo)

SOUZA, J. L. e RESENDE, P. Manual de horticultura orgânica. Viçosa, Aprenda Fácil. 2003.

WATANABE, M. A. Agricultura orgânica: uma alternativa saudável e ecologicamente correta. A Lavoura, 18-19, 2000.

ZAMBERLAM, J. e FRONCHETI, A. Agricultura ecologica: preservação do pequeno agricultor e do meio ambiente. Petrópolis, Vozes, 2001. 214p. 